DOI: $10.17516 / 1997-1370-0574$

УДК 902.01

\title{
A Study on the Rock Art of the Tongtian River Basin, Tibetan Plateau of China
}

\author{
Zhang Wenjinga and Wang Xiaokun*b \\ ${ }^{a}$ Anyang Normal University \\ Wenfeng District, Anyang, Henan, China \\ ${ }^{b}$ Renmin University of China \\ Haidian District, Beijing, China
}

Received 10.10.2019, received in revised form 22.01.2020, accepted 18.10.2020

\begin{abstract}
In recent years, the Yushu Museum has conducted a systematic investigation on the rock art of the Tongtian River Basin in its prefecture and newly discovered 1230 panels' rock art (more than 1700 images). This paper is a statistical and comparative analysis of the newly discovered rock art. According to content and production techniques, we divided the rock art of the Tongtian River Basin into two big areas. The West Area is the upper part of the river basin, which is the area above the confluence of Tongtian River and Chumar River (Qumalai River); the East Area is the lower part of the river basin, which is from the confluence to the Batang estuary of Yushu. This area can be subdivided into three subareas.

The majority of the Tongtian River Basin's rock art is categorized as animal type. Yak and deer are respectively the main themes of the West Area and the East Area. In addition, there are other rock art types like symbol, character, pagoda, carriage and so on. The two areas have both commonalities and their own characteristics. Through the typological analysis of production techniques, in the cases of carriage rock art, and deer rock art, we think that the rock art mainly used the whole-image chiseling technique. This technique can be traced back to the Shang Dynasty; the rock art mainly chiseled linearly is dated to the early Zhou Dynasty to the Warring States Period; the rock art that was creates with the line carving technique is dated to the Warring States Period to the Western Han Dynasty; the rock art that was creates with the grind carving technique can be dated back to the Qin and Han dynasties; and the rock art mainly used scratching technique can be traced back to the Ancient Tibetan Empire Period (618-842 AD).
\end{abstract}

Keywords: Rock art, Tongtian River Basin, Tibetan Plateau.

This paper is supported by the scientific research fund, Renmin University of China.

Research area: archeology.

(C) Siberian Federal University. All rights reserved

* Corresponding author E-mail address: pmandryka@yandex.ru 
Citation: Wenjing, Z., Xiaokun, W. (2020). A study on the rock art of the Tongtian River Basin, Tibetan Plateau of China. J. Sib. Fed. Univ. Humanit. Soc. Sci., 14(1), 111-127. DOI: 10.17516/1997-13700574 .

The Tongtian River is the main stream of the Yangtze River's source section. It got its name from its high terrain, because it originates from the Roof of the World, the Qinghai-Tibet Plateau. The Yangtze River originates from the Tuotuo River, whose source is located in the hinterland of the Qinghai-Tibet Plateau, flowing out from the $5820 \mathrm{~m}$ snowline of the Southwest side of the Jianggendiru Peak, the Geladandong Snow Mountains, the middle part of the Tanggula Mountains. The 44 kilometers' valley area of the snow mountain is called Naqinqu, thereinafter known as Tuotuo River. Flowing passing $346 \mathrm{~km}$ from the snow line, it joins together with the south source Dangqu River in Nangbalong, below the confluence known as Tongtian River. Flowing passing $278 \mathrm{~km}$ from the Nangbalong, it flows together with the north source Chumar River, above the confluence known as the upper part of the Tongtian River. From the Chumar River confluence to the Batang Estuary of Yushu is the lower section of the Tongtian River (Liu, 2014). The river flows across the Yushu Tibetan Autonomous Prefecture of Qinghai province, which is located in the southwest of Qinghai Province, with area of 267,000 square kilometers, accounting for $37.02 \%$ of the total area of Qinghai, having jurisdiction over 6 counties, like Yushu, Nangqian, Chenduo, Zaduo, Zhiduo, Qumalai,1 town and 47 townships (The Annals of Yushu, 2005). The Yushu Tibetan Autonomous Prefecture is located in the middle of the South-Qinghai Plateau, with relatively gentle terrain and not big relative height difference. The river cutting trace here is not obvious and the plateau surface shape is relatively complete. What's more, it's the headstream of Yangtze River, Yellow River, and Lancang River, so it's called "rivers source."

From December 2013 to April 2016, the Yushu State Museum carried out numerous investigations on the rock art of the Tongtian River Basin, which were mainly found on the cliffs or scattered rocks on both banks of the river and its tributaries. 21 sites, 1230 panels, and a total of more than 1700 images were discovered, which were twice the number of all other rock art in Qinghai province (NimaJiangcai, 2016). This paper analyses and explores the zoning, regional characteristics and the dating of rock art in the Tongtian River Basin.

\section{The zoning of the Tongtian River \\ Basin's rock art}

\section{The production techniques of rock art}

Rock art refers to the images and symbols engraved, using stone or metal tools, or painted, using mineral pigments, by ancient people on the outdoor rocks or cave walls. So, in general, there are two types of rock art: carved rock art and painted rock art. The northern Chinese rock art were mainly carved, rarely painted. The techniques of carved rock art can be divided into chiseling and grinding. Chiseling is mainly composed of whole-body chiseling, shaped by the whole image and showing silhouette-like images in dense chisel-points, and linearly chiseling, shaped by lines and showing images in carved lines, with both carved by stone or metal tools. The rock art used linearly chiseling technique has thick lines and obvious chisel-points. And the linearly chiseling technique can be subdivided further into line carving technique, which carves lines with metal tools, and grind carving technique. The lines carved in line carving technique are generally thinner, visually slender and more smoother, and with more vivid images than that in the linearly carving technique; as for grind carving technique, the outline of the images are first carved, then the metal or stone tools are used to repeatedly grind lines, so this kind of images often have more clear lines and deeper grooves. We find that in the grind carving technique, if stone tools are used to repeatedly grind images in a long-term, the groove would be U-shaped, deep and wide, and details cannot be very clear. Such technique was widely used in human face rock art in Yinshan (Wang, Zhang, 2012). If metal tools are used for grinding, the groove would be V-shaped and the lines would be 
slender. Within the grinding technique, there are two other types. One is that after carving out the outline of the image, to grind the whole image entirely rather than to grind the lines of the carved outline; another is that to directly use metal tools to scratch images without carving process. In order to differentiate these techniques, we call the technique of directly scratching with metal tools as scratching technique.

In the Tongtian River Basin, chiseling, especially whole-image chiseling and linearly chiseling are the main production techniques, and the line carving technique is also used more, while the scratching technique used less. Painted rock arts are very few, only found 2 in Xieqinggou, Bagan Township,Qumalai County.

\section{The zoning of the Tongtian River Basin's rock art}

Through the analysis of the production techniques at each rock art site, combined with the quantity of the rock art types, we zoned the rock art in the Tongtian River Basin to clarify the distribution of the rock art and lay the foundation for further analysis.
We zoned the rock art in the Tongtian River Basin into two areas. The West Area is the upper section of the river; the East Area is the lower section of the river. The East Area is subdivided into three subareas: Subarea I, Subarea II and Subarea III. (Fig. 1).

The West Area includes rock art sites Lechi, Angla, Zhilong, Zhangma, Niangzabama, Rongxiong, Zhangnang, and Gemma. In the East Area, the Subarea I includes rock art sites Tajiong, Ganglongwoma, Zhangqida, Keyoushan, Yunta, Bise, Gaqiong, Jiaokao, Lengpeita, and Pukagongma; the SubareaII has Zongqing, Xieqing, Tongji, Quzi, Nixichajia, Kalong, Saikang, Muxu, Mumosangduo, and Dongguo; the SubareaIII Includes Gengzhuo, Lagong, Bulang, Maisong, and Juese.

\section{The regional distribution characteristics of the Tongtian River Basin's rock art \\ 1. The West Area - the upper section of the Tongtian River}

The West Area is the Northern Qumalai County, including rock art sites Lechi, Angla, Zhilong, Zhangma, Niangzabama, Rongxiong, Zhangnang, and Gemma in Qumahe Township

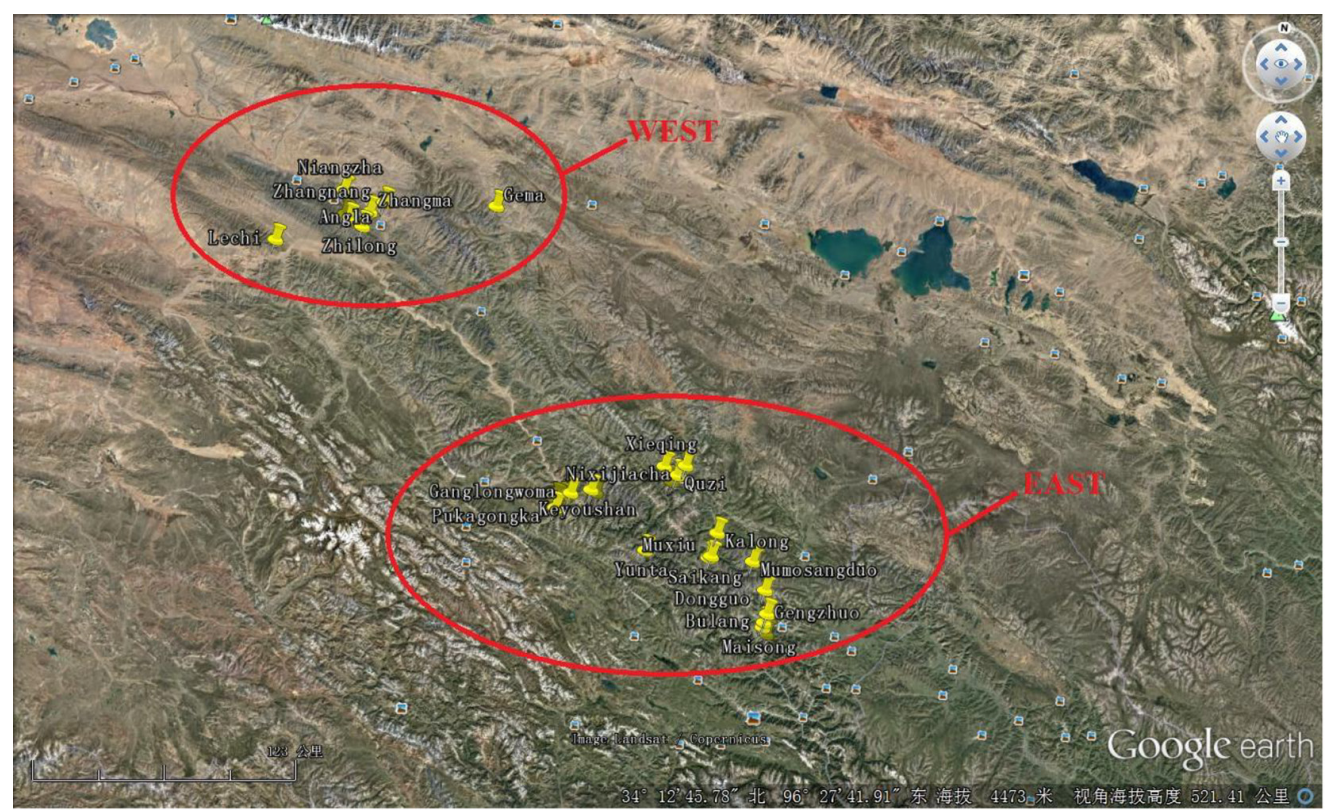

Fig. 1. The zoning distribution of Yushu rock art. This was made by Google Earth according to the three-dimensional coordinate of the rock art sites in Yushu Rock Art: Tongtian River 


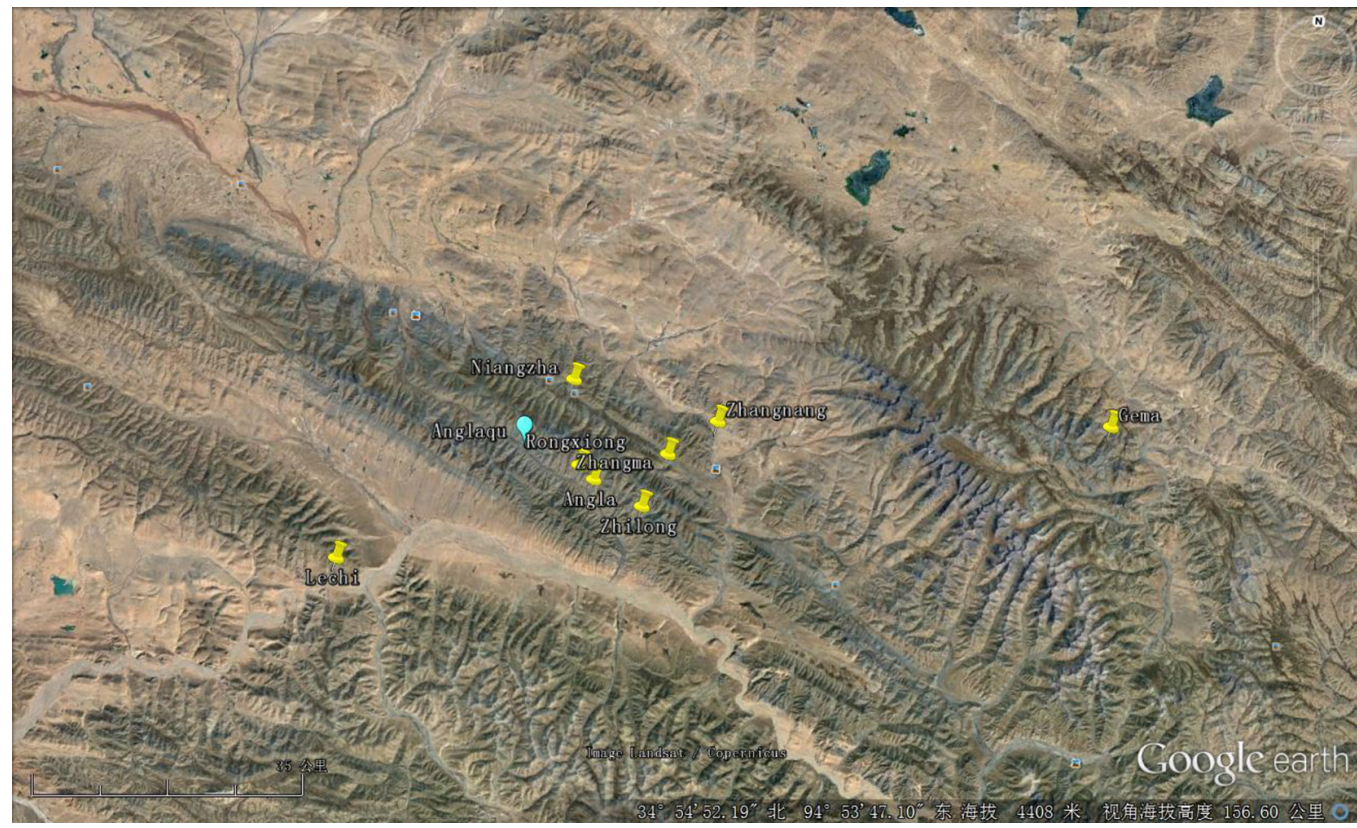

Fig. 2. The rock art distribution of the West Area

(Fig. 2). These rock art sites are located in the valley near the Tongtian River and its tributary Chumar River (also called Qumahe).

The West Area is located in the upper part of the river basin, in the hinterland of the Qinghai-Tibet Plateau. The landform is a wavy plateau; with a gentle slope to the east. Most valleys are shallow and broad. And the elevation here is between 4000 and 5400 meters above sea level. The tributaries of Tuotuo River and Dangqu River converge are in the fault basin of the north of the Tanggula Mountains, with the river system in a fanshaped arrangement. The whole uplift of the river source area forms a complete plateau surface, and the rivers' head ward erosion is currently confined to the plateau. The main rivers of the river source have relatively gentle riverbed profile, except rivers stemming from mountains. From the source to the mountainous region of Bolongqukou, this section of Tuotuo River is $126 \mathrm{~km}$ long, with an average gradient degree of about $5.4 \%$; the section from Bolongqukou to Nangbalong was wandering river section with broad valley, having $220 \mathrm{~km}$ long and an average gradient degree of $1.3 \%$,with wide and shallow river- bed, dense channels, and rich sandbanks; the section from Nangbalong to Chumar estuary is the upper part of the Tongtian River, with the river having branching and wandering nature, and an average gradient degree of about 0.9\%o (Liu, 2014).

This area is dominated by animal rock art (Fig. 3). Among these, the yak rock art is the most abundant (Fig. 4). The rock art types such as rider, character and symbol are less frequently found. Symbol rock art are mostly symbols of Yong-zhong. There are only 4 carriage rock art images. The rider rock art and the shooter rock art may indicate of herding and hunting activities.

Through investigating the distribution of this region's production techniques, we can conclude that the production techniques of the West Area's rock art is mainly chiseling, especially whole-image chiseling, and the proportion of the rock art that used line chiseling and the line carving technique is rather small, with no evidence of grind carving technique (We do not analyze the making technics of unknown works) (Fig. 5). Overall, the production techniques and rock art types of this area tend to be consistent. 


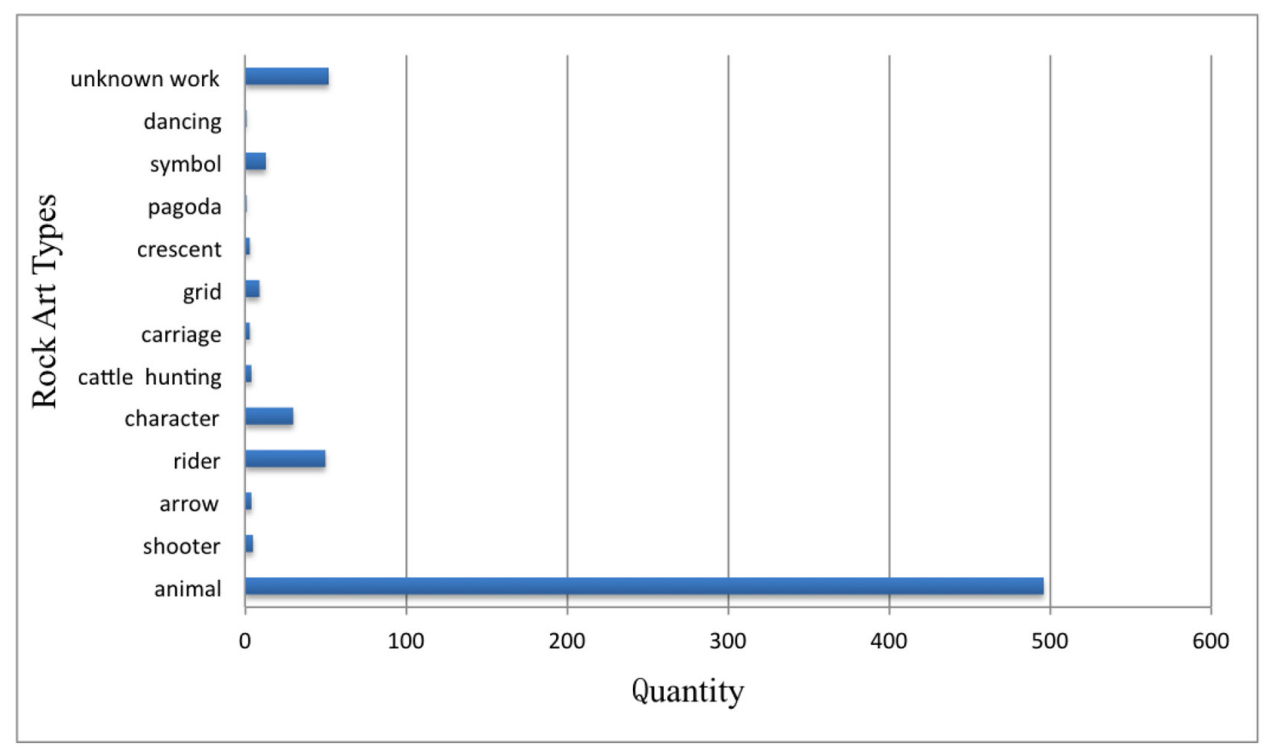

Fig. 3. Diagram of types and quantity of the West Area's rock art In this paper, a single image for statistics

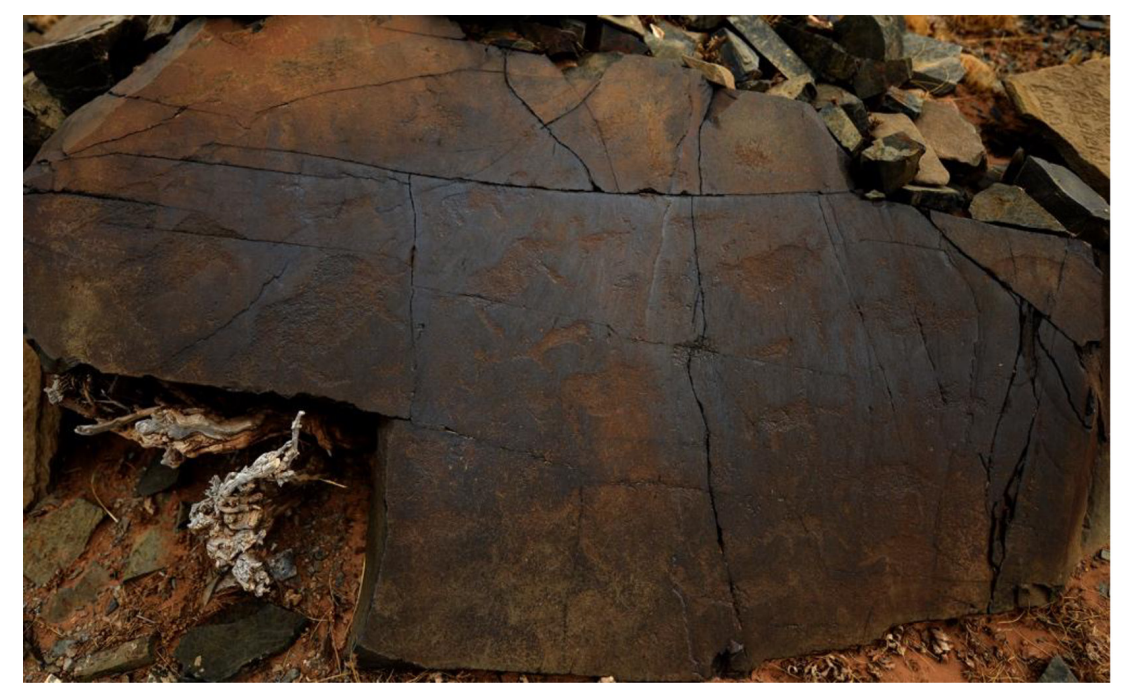

Fig. 4. Lechi rock art (provided by Yushu Museum). The rock-face is $57 \mathrm{~cm}$ high, $98 \mathrm{~cm}$ wide, in $100^{\circ}$ direction, with an inclination of $50^{\circ}$. The technique is whole-image chiseling.

There are 21 single yak rock art, 1 rider rock art, 6 single leopard rock art, 1 wolf rock art, 1 leopard hunting cattle rock art, and 1 unknown work on the rock-face) (NimaJiangcai, 2016)

\section{The East Area - the lower section of the Tongtian River}

The lower section of the river is a large area (Fig. 6). From the Chumar River confluence to the Batang estuary of Yushu is the lower section of the Tongtian River Basin, which is about $550 \mathrm{~km}$ long. The river valleys are gradually curved and narrow. The landform is high mountain-deep valley and typical ingrown meanders are developed. The average gradient degree from the confluence to Dengequkou is $1.1 \%$, while the average gradient degree from Dengequkou to the Batang estuary is $1.5 \%$. The tributaries of this section are mainly the Bangbayong, Jin- 


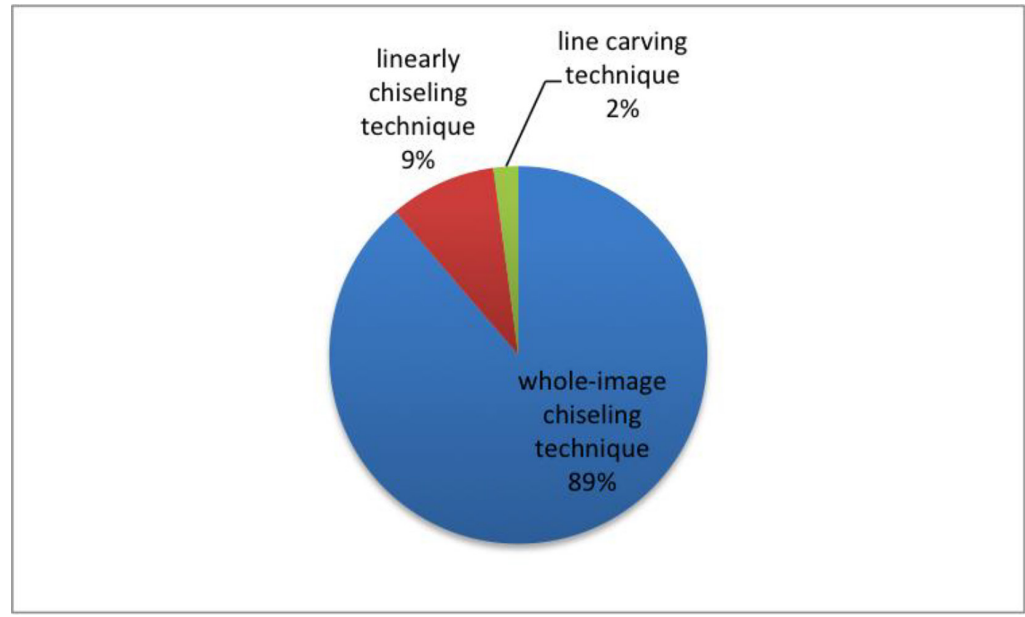

Fig. 5. The proportion diagram of production techniques of the West Area's rock art

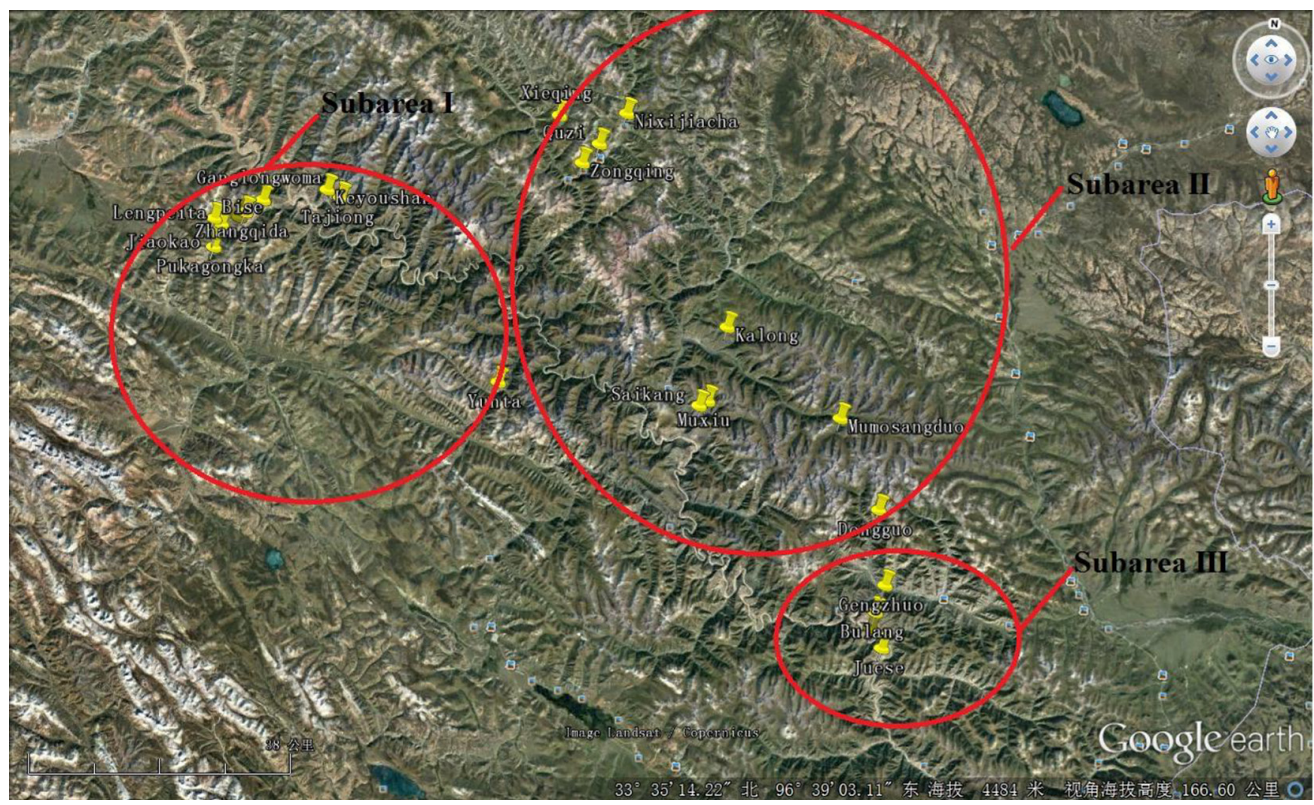

Fig. 6. The distribution of the East Area's rock art

wuqu, Dengenyong, Nieqiaqu, Dequ, Xiqu and Batang Rivers. The Tongtian River flows out of Qinghai province, into the longitudinal rangegorge region of southwest China, at which it is renamed as the Jinsha River. Finally, we subdivided this large area into three subareas.

\section{(1) Subarea I}

This area includes the rock art sites of Tajiong, Ganglongwoma, Zhangqida, Keyoushan,
Yunta, Bise, Gaqiong, Jiaokao, Lengpeita, and Pukagongma. The Tajiong rock art site is located in the Yuegai Town, in the southeast of Qumalai County.The rock art sites of Ganglongwoma and Zhangqida in the Lixin Township, Zhiduo Town is separated from Tajiong by the Tongtian River. The Keyoushan rock art site is located in the Yeqing village, Lixin Township. The Yunta rock art site is located in the Yunta village, Haxiu Township,Yushu City. 
The main rock art type in this area is animal rock art. Besides, other rock art types such as symbol, rider, character, shooter, and pagoda can be found here and there are also 6 carriage rock art images (Fig. 7, Fig. 8).

As for the production techniques, linearly chiseling are mainly used, followed by wholebody chiseling and line carving technique, and the scratching technique is less frequently found (Fig. 9).

\section{(2) Subarea II}

This area includes the rock art sites of Zongqing, Xieqing, Tongji, Quzi, and Nixichajia. These sites are located in Bagan Township of Qumalai County, Dongguo in Chengwen Town, and Kalong, Saikang, Muxu, Mumosangduo in Gaduo Township, of Chengduo County.

There are only 146 rock art panels in this region. And the main types also animal, followed by some types of checkerboard, rider, arrow, symbol, etc. (Fig. 10, Fig. 11).

The main production techniques of this area's rock art are the line carving technique, followed by linearly chiseling and the scratching technique. The proportion of the whole-im- age chiseling technique is small. There are also painted rock art. (Fig. 12).

\section{(3) Subarea III}

Subarea III includes the rock art sites Gengzhuo, Lagong, Bulang, Maisong, and Juese. Gengzhuo and Lagong are located in Chengwen Town, Chengduo County. Bulang is located in Anchong Township, Yushu City. While the sites of Maisong and Juese are located in Dazhong Township, Yushu City.

Animal rock art is prominent, while other rock art types like symbol, character, pagoda, and rider are less abundant (Fig. 13, Fig. 14).

As for production techniques, the linearly chiseling technique is the prominent, followed by the whole-image chiseling and line carving technique (Fig. 15).

The quantitative analysis above on the types and distribution of the Yushu rock art make the overall characteristic of Yushu rock art basically clear.

According to the content and production techniques, we divided the Yushu rock art into two large areas, the East and the West. The West Area is mainly in the upper section of the Tongtian River. The major rock art type is

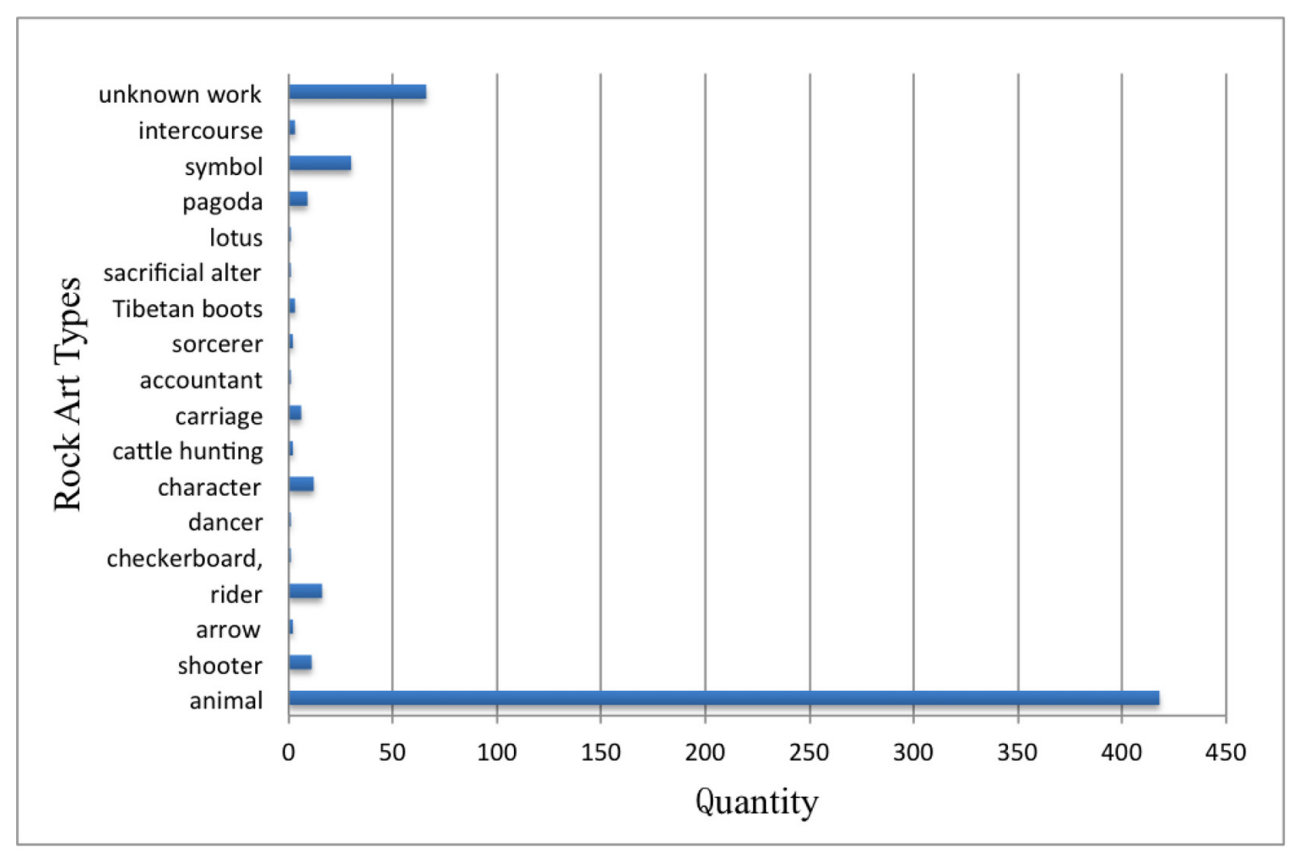

Fig. 7. Diagram of types and quantity of the Subarea l's rock art 


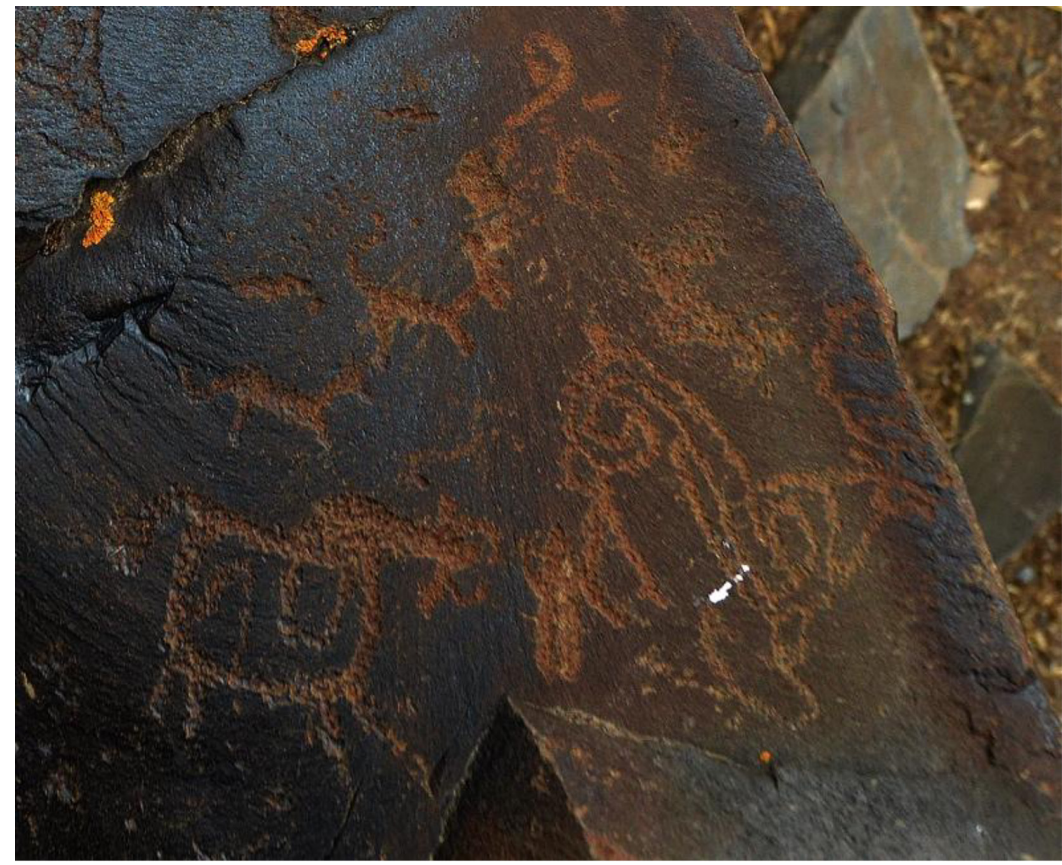

Fig. 8. Tajiong rock art (provided by Yushu Museum). The rock-face is $45.46 \mathrm{~cm}$ high, $44.22 \mathrm{~cm}$ wide, in $155^{\circ}$ direction, with an inclination of $160^{\circ}$. The technique is linearly chiseling.

There are yak rock art, shooter rock art, deer rock art, dog rock art on the rock-face) (NimaJiangcai, 2016)

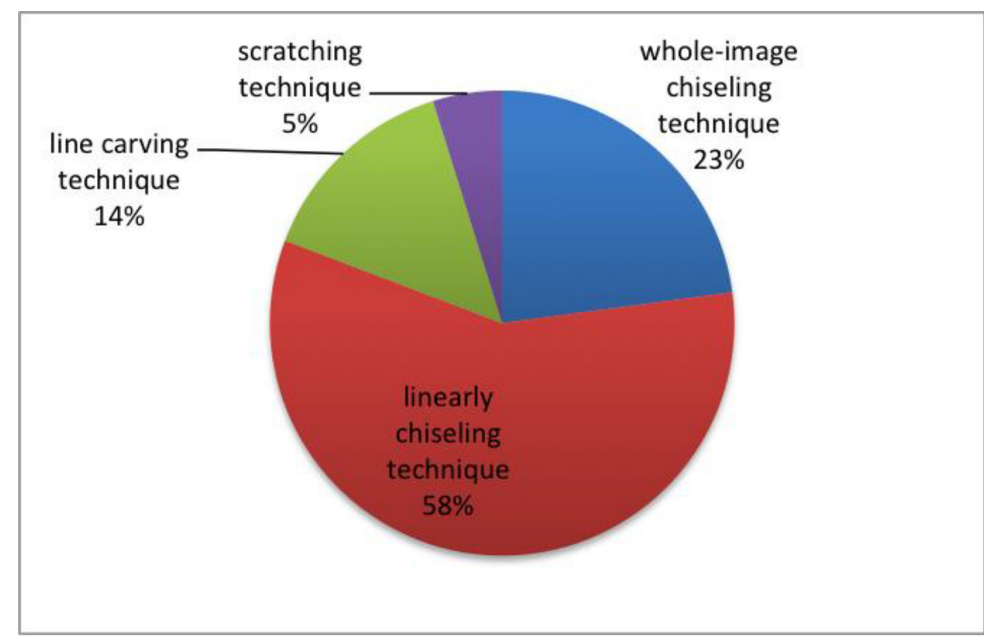

Fig. 9. The proportion diagram of production techniques of the Subarea l's rock art

animal, with 496 panels. Among these animal rock art images, the yak is the most abundant, followed by deer, while other animals like leopard, sheep, horse, and dog are also portrayed. Other major rock art types in this area are rider, character, symbol, hunting, and vehicle.
The East Area is mainly in the lower section of the Tongtian River, which is subdivided into three subareas according to different characteristics. In Subarea I, the major rock art type is animal. There are 418 panels in total, of which the yak rock art is the most abundant, followed 


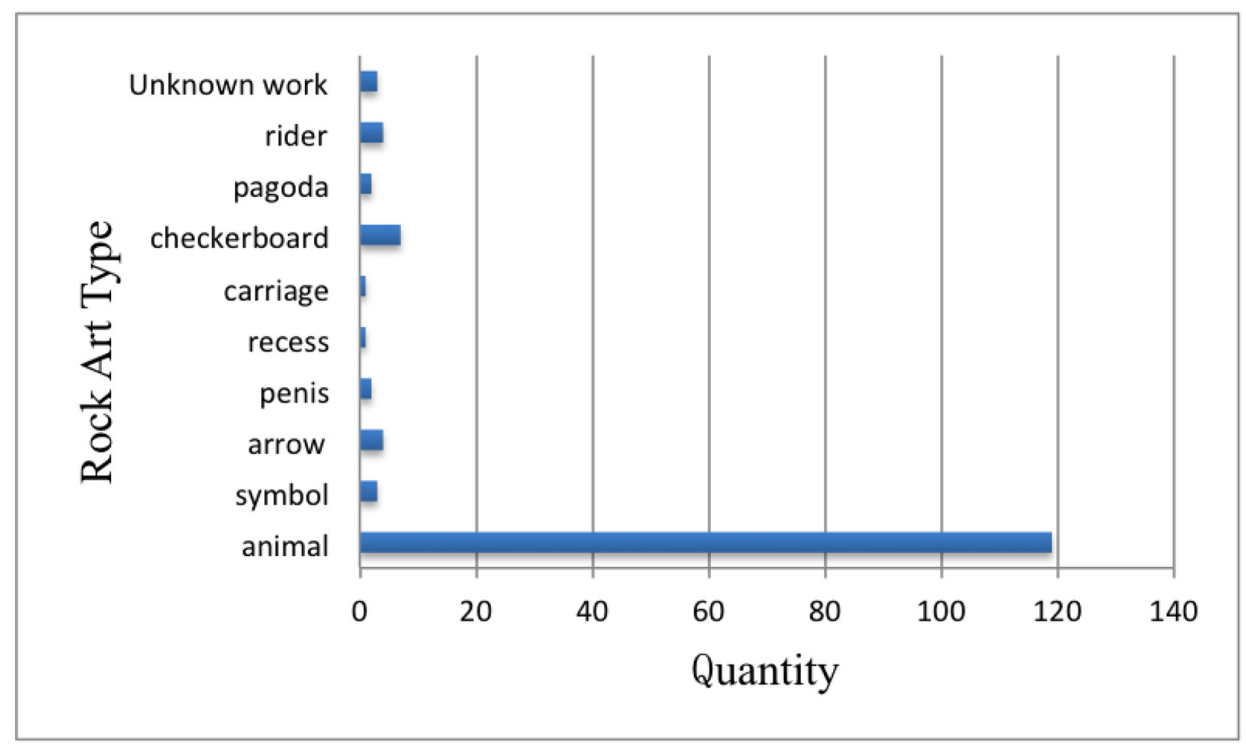

Fig. 10. Diagram of types and quantity of the Subarea II's rock art

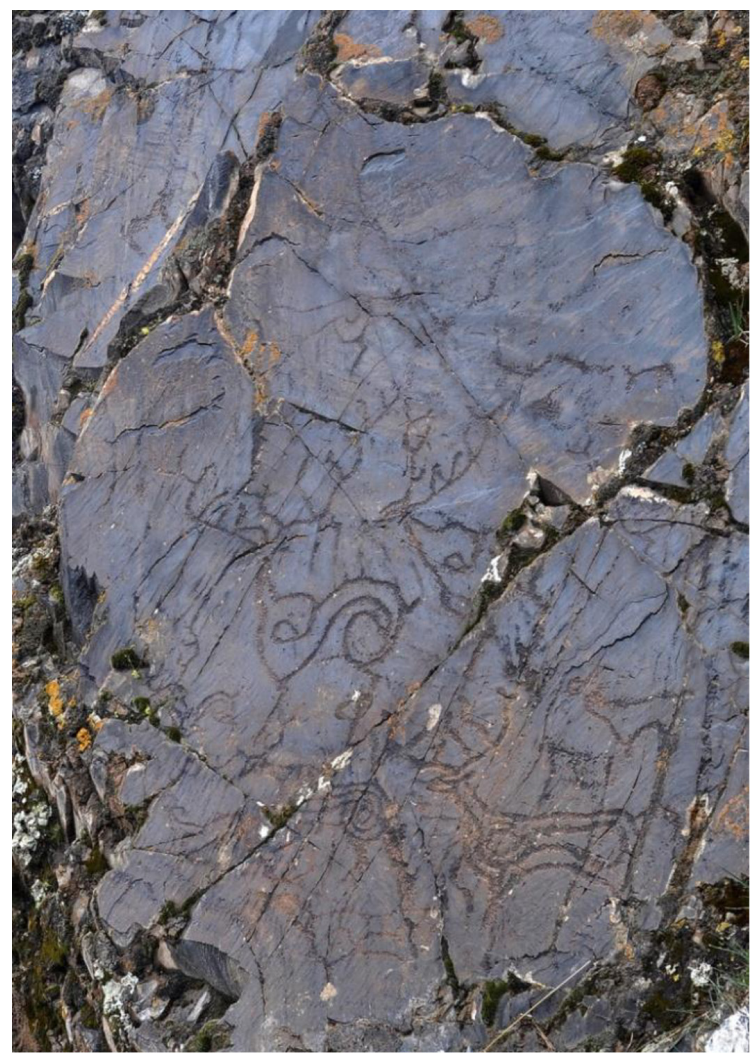

Fig. 11. Saikang rock art (provided by Yushu Museum). The rock-face is $120 \mathrm{~cm}$ high, $166 \mathrm{~cm}$ wide. The technique used is line carving. There are 9 single deer rock art, 1 yak rock art,

1 dog rock art, 1 leopard rock art and 1 unknown animal on the rock-face (NimaJiangcai, 2016) 


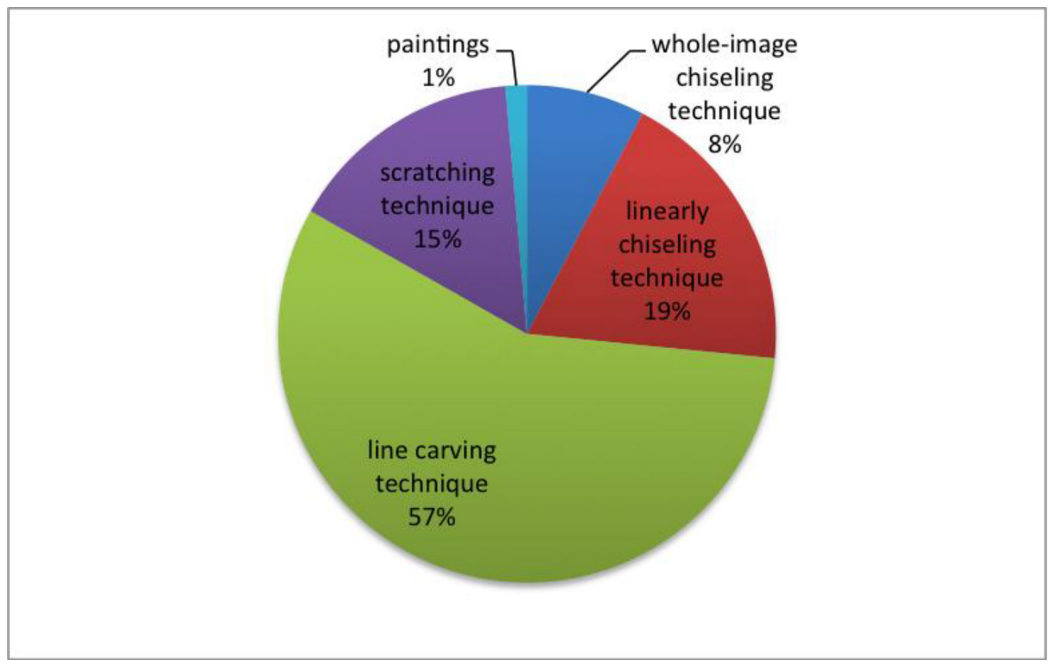

Fig. 12. The proportion diagram of production techniques of the Subarea II's rock art

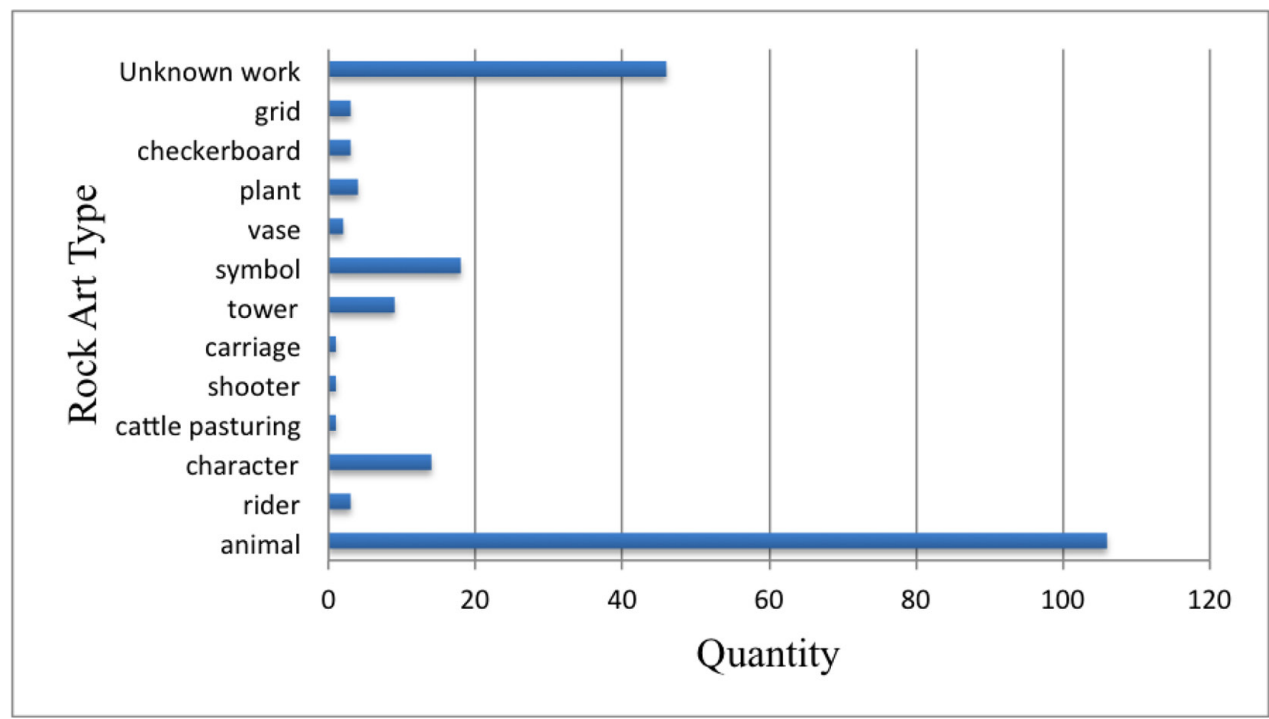

Fig. 13. Diagram of types and quantity of the Subarea III's rock art

by deer, sheep, dog, and leopard. Deer rock art images are scattered at almost every site. Other major rock art types are symbol, character, pagoda and carriage. Subarea II is also dominated by animal rock art with 119 panels. Deer images are the most abundant, followed by yak, sheep, leopard, dog and horse. Chessboard, symbol, rider, and pagoda types have also been found. In Subarea III, the major rock art type is also animal. There are 97 panels animal rock art. Among these, the yak rock art is the dominant type. Deer, dog, sheep and horse are secondary. Other major types include symbol, character, pagoda, plant, chessboard, and grid. Chessboard and the pagoda rock art are mainly distributed throughout the East Area.

As for the production techniques, the West Area is dominated by the whole-image chiseling technique, supplemented by linearly chiseling and line carving technique, with no grind carving technique. In the East Area, Subarea I is dominated by linearly chiseling technique, 


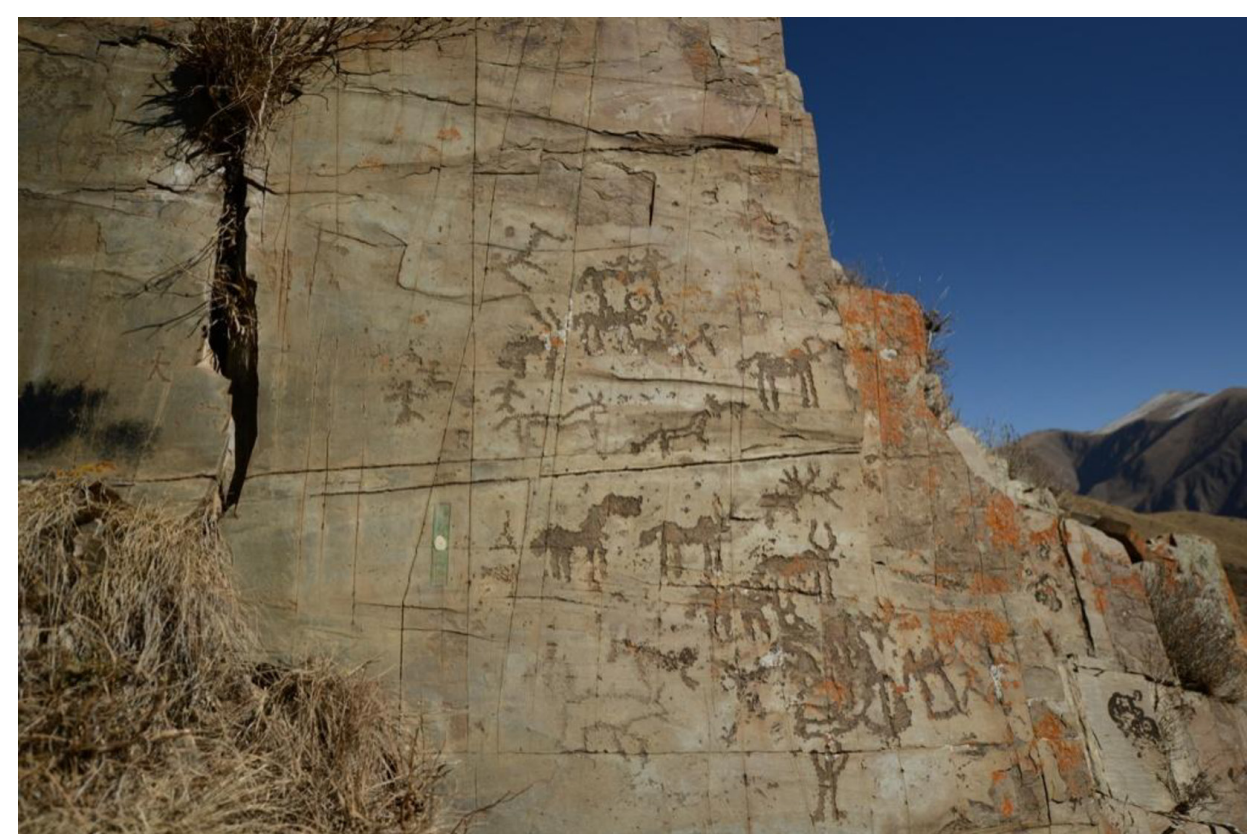

Fig. 14. Juese rock art (provided by Yushu Museum). The rock-face is $135 \mathrm{~cm}$ high, $200 \mathrm{~cm}$ wide, in $110^{\circ}$ direction, with an inclination of $84^{\circ}$. The techniques used are whole-image chiseling and linearly chiseling. There are 7 single yak rock art, 2 rider rock art, 3 character rock art, 1 leopard rock art, 1 dog rock art, 1 horse rock art, 1 deer rock art, and 2 unknown work on the rock-face (NimaJiangcai, 2016)

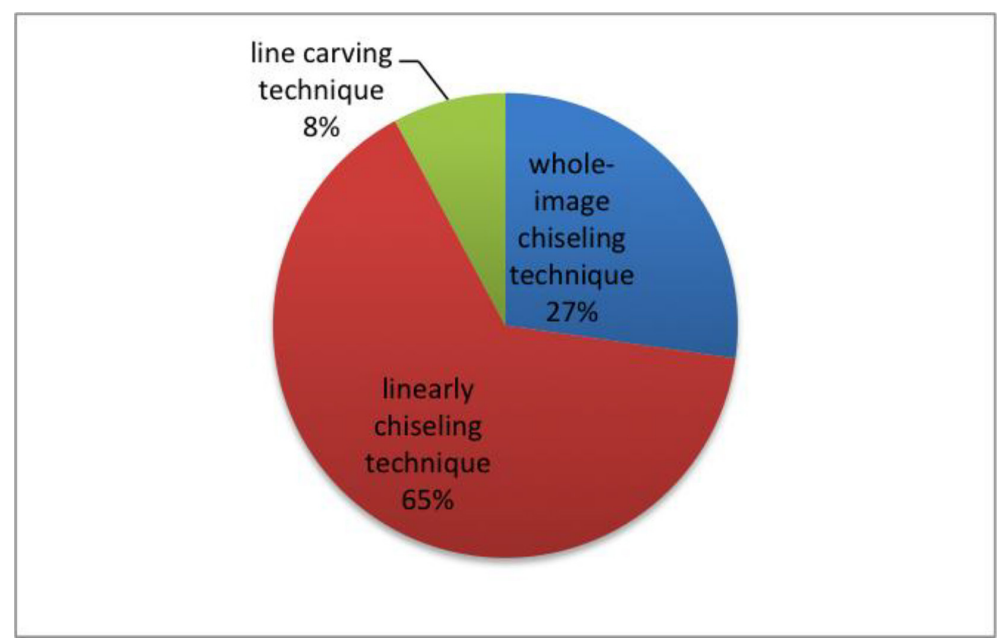

Fig. 15. The proportion diagram of production techniques of the Subarea III's rock art

followed by whole-image chiseling and line carving technique, with little scratching technique. In Subarea II, the line carving technique is the mostly widely used, while linearly chiseling and scratching techniques are secondary, and painted rock art and rock art used the whole-image chiseling technique occupy a small proportion. Subarea III is dominated by the linearly chiseling technique, followed by whole-image chiseling and line carving technique. Therefore, in a whole, the East Area is dominated by linearly chiseling and line carv- 
ing technique and the usage of whole-image chiseling technique is substantially lower.

\section{The dating of the Tongtian River}

\section{Basin's rock art}

\section{The application of typology in the study of rock art}

Typology is the most basic methodology of archaeology. The study of rock art can also use typology for reference. Through the analysis on the regional characteristics of the Tongtian River Basin, we know that the main production techniques are whole-image chiseling, linearly chiseling and line carving technique. In the study of rock art, different techniques are of great significance. Rock art that is created with the same technique is regarded as part of the same group. This just like a snowball, the more the associated features the rock art has, the more reference points it has for solving many problems, such as the dating. For example, using production techniques, we divide the rock art of the Tongtian River Basin into different groups. Each group may have combinations of yak rock art, sheep rock art, deer rock art, carriage rock art and character rock art. That is, because of different production techniques, these different types belong to different group. Each group has some "diagnostic artifacts" to determine the relative age or the time sequence of rock art; "diagnostic artifacts" include carriage rock art, deer rock art.

\section{The discussion on the dating of rock art}

As mentioned above, we divide the rock art respectively used whole-image chiseling, linearly chiseling, and line carving technique into different groups, while each group may have combinations of. Because of different production techniques, these different types belong to different groups. Each group has some artifacts to determine the relative age or the time sequence of rock art, such as the "diagnostic artifacts" like carriage rock art, deer rock art.

First of all, we start with the carriage rock art. In China, the usage of carriage was relatively late, which can only be traced back to the late Shang Dynasty. At that time, the char- iot with two horses was commonplace and the structure of carriage is well known (Sun Ji, 2008). Moreover, from the Shang Dynasty to the end of the Spring and Autumn Period, the carriage was built with only one hitch. The specific structure was one shaft and double wheels, with the rear part of the shaft located at the bottom of the carriage and it intersected the axle vertically. In front of the shaft was the cross tie, with the yoke tied to it. The yoke was on the two sides of the shaft, which was used to harness the horse. During the Warring States Period, double shaft carriages began to appear. There was a time when single shaft carriages and double shaft carriages existed simultaneously. In the early Western Han Dynasty, the single shaft carriage was still very common. Not until the late Western Han Dynasty, the double shaft carriage gradually replaced the single shaft carriage. The single hitch carriage was dominated by standing riders; using the Yoke-Strap riding method (Fig. 16). The one hitch carriage needed at least two horses. Four horses one hitch carriage configuration exists, one was unearthed in the 1st tomb of Dabaotai in Beijing (Western Han Dynasty). The double shaft carriage was dominated by sitting riding, using the Chest-strap riding method. It only needed one horse, although there were a few using three horses (Sun Ji, 2008). In comparison, the double shaft carriage was more advanced. But most of the chariots and carriages used by noblemen mentioned in the documents of pre-Qin Dynasty were one hitch carriage. Therefore, one hitch carriage represented the carriage of the ancient times in China (Sun Ji, 2016). The Shang Dynasty bronze inscriptions

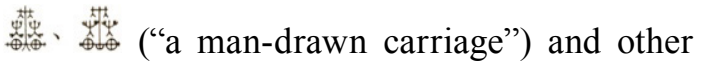
words, as well as the images of carriage carved on bone (Fig. 17), all revealed the structure of the one hitch carriage.

The carriage rock art of the Tongtian River Basin was all one hitch (Table 1, Fig. 18). We divided the age of the one hitch carriage rock art into the following ranges: the terminus ante quem was the Spring and Autumn Period (770 BC-476 BC), continuing to Qin or Han dynasty, and terminus post quem can be extended to the Shang Dynasty (1600 BC-1100 BC) or 


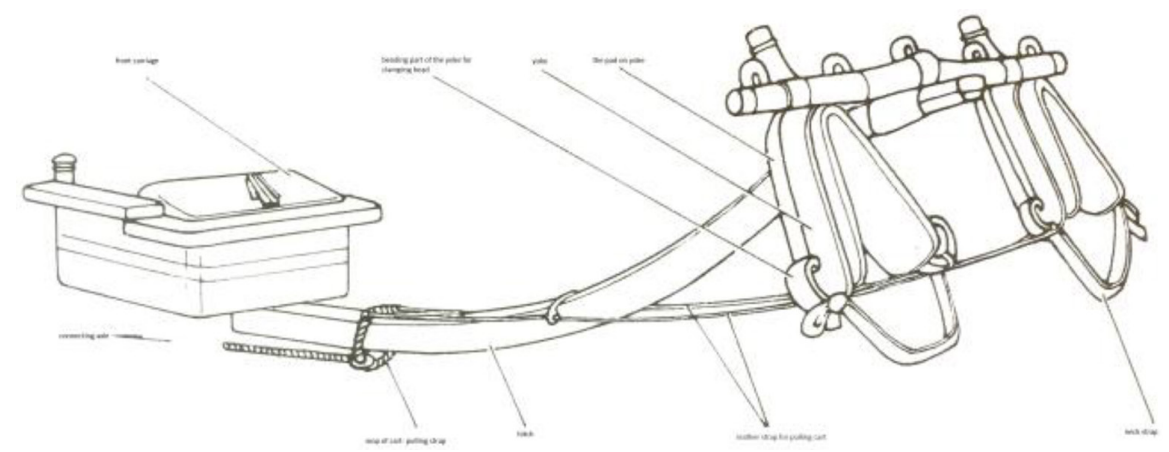

Fig. 16. The sketch drawing of the one hitch carriage's (According to the 2nd bronze carriage in the Mausoleum of the First Qin Emperor) ) (Sun Ji, 2016)

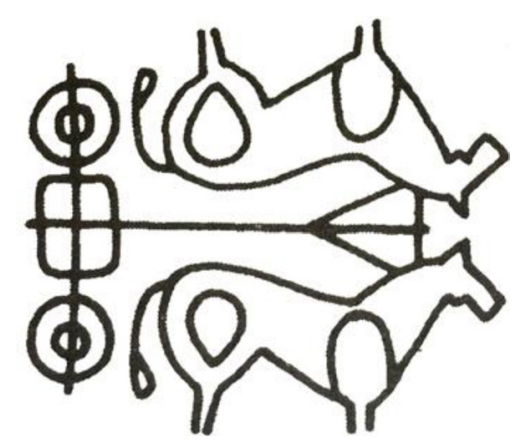

Fig. 17. Bone carving. Yoke-Strap riding method

(Ningcheng, Inner Mongolia, the Warring States Period) (Sun Ji, 2016)

Table 1. Distribution of carriage rock art in the Tongtian River Basin

\begin{tabular}{|c|c|c|c|c|c|l|}
\hline Rock art Site & Number & Shaft & $\begin{array}{c}\text { Carriage } \\
\text { (The riding part) }\end{array}$ & Wheel & $\begin{array}{c}\text { Draft } \\
\text { animal }\end{array}$ & \multicolumn{1}{|c|}{ Production techniques } \\
\hline \multirow{3}{*}{ Angla } & 2 & 1 & Yes & 2 & Yes & $\begin{array}{l}\text { The carriage and draft animal: } \\
\text { whole-image chiseling; the other: lin- } \\
\text { early chiseling }\end{array}$ \\
\hline \multirow{5}{*}{ Tajiong } & 1 & 1 & Yes & 2 & Yes & $\begin{array}{l}\text { The carriage and draft animal: } \\
\text { whole-image chiseling; the other: lin- } \\
\text { early chiseling }\end{array}$ \\
\cline { 2 - 8 } & 1 & 1 & Yes & 2 & Yes & linearly chiseling \\
\cline { 2 - 8 } & 2 & 1 & Yes & 2 & 4 horses & Line carving \\
\cline { 2 - 8 } & 1 & 1 & Yes & 2 & $\begin{array}{c}\text { Un- } \\
\text { known }\end{array}$ & linearly chiseling \\
\hline Gema & 1 & 1 & Yes & 2 & No & linearly chiseling \\
\hline Bise & 1 & 1 & No & 1 & No & linearly chiseling \\
\hline Muxu & 1 & 1 & Yes & 2 & No & linearly chiseling \\
\hline Gengzhuo & 1 & 1 & Yes & 2 & No & $\begin{array}{l}\text { The draft animal: whole-image chisel- } \\
\text { ing; the other: linearly chiseling }\end{array}$ \\
\hline
\end{tabular}




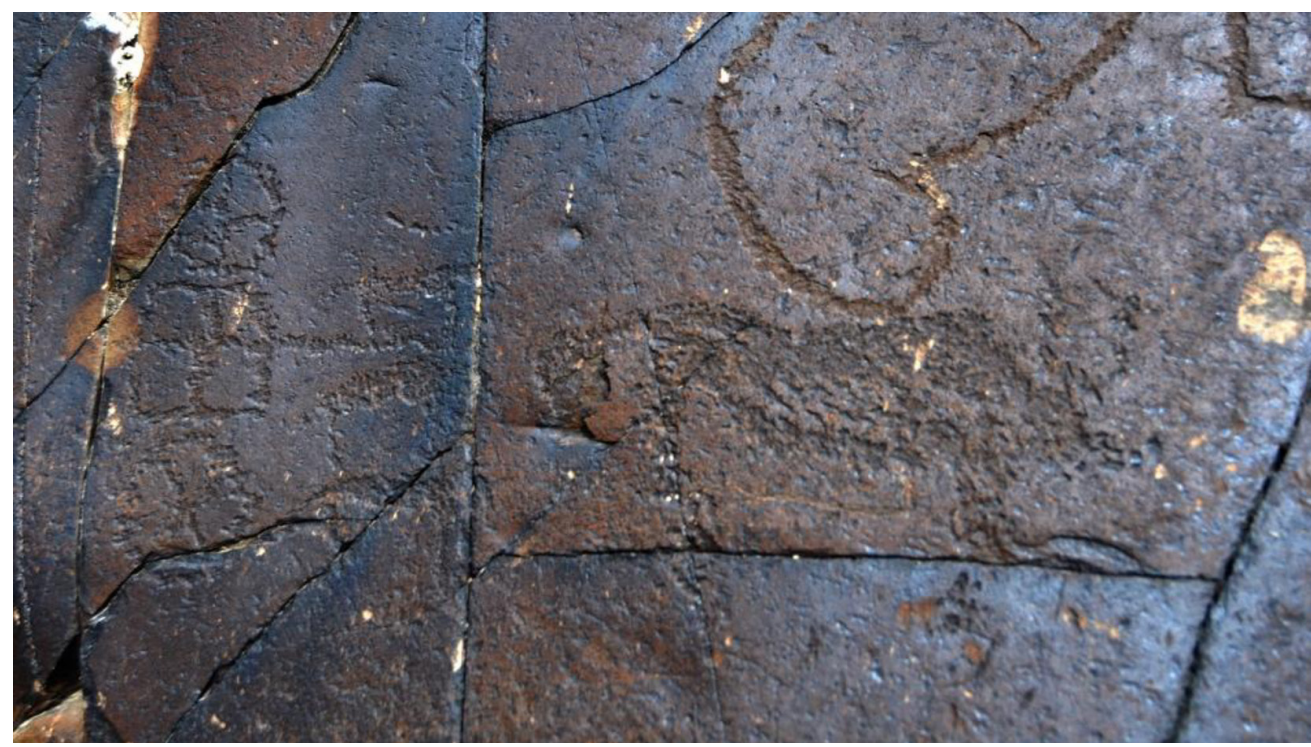

Fig. 18. Gengzhuo rock art (provided by Yushu Museum). The carriage rock art is located at the left side of the frame, with a height of $10.90 \mathrm{~cm}$ and a width of $23.40 \mathrm{~cm}$.

The draft animal used whole-image chiseling technique, and the carriage part used linearly chiseling technique(NimaJiangcai, 2016)

even earlier (Zhang, 2013). Then, the age frame of the carriage rock art of the Tongtian River Basin contained the whole-image chiseling, linearly chiseling, and line carving technique. The draft animal subgroup of carriage rock art that used the whole-image chiseling was in a group under the whole-chiseling technique. Similarly, the carriages used the linearly chiseling and line carving techniques can be dated back to the same age with the other types' rock art with the same technique.

From the distribution of the carriage rock art in the Tongtian River Basin, the number of the whole-image chiseling rock art is lower. An image carriage rock art in the Yeniugou, which can be dated back to the Shang Dynasty, has the same shape and structure with that of the Tongtian River Basin. Their draft animals both used the whole-image chiseling technique. The linearly chiseling rock art is the most common technique, which indicates that the usage of carriage in this time, approximately late Shang and early Zhou Dynasty. The number of the line carving rock art is the lowest. One of them had a carriage with four horses and one shaft, which was uncommon. The age of the line carving carriage rock art may be later than the linearly chiseling carriage rock art, and its age was roughly in the Warring States period to the Western Han Dynasty.

Secondly, let's move to the deer rock art. There are 219 examples of deer rock art in the Tongtian River Basin. Based on the previous analysis of production techniques with regional characteristics, the deer rock art mainly used the line carving technique, secondly used the linearly chiseling and whole-image chiseling technique. The former two were mainly distributed in Subarea I and II of the East Area, while the latter were located in the West Area. From the perspective of modeling, the deer carved by whole-image chiseling technique were a little clumsy and stiff, with huge and bulky-branched antlers. While the deer carved by line carving or linearly chiseling technique mostly had motifs, like whirls, moirés, S-straps and so on, with big and branched antlers, and their body lines were flowing, so their images were dynamic and vivid (Fig. 11). The images of deer motifs carved by linear carving and linearly chiseling techniques were influenced by the Scythian artistic style, which was roughly in the Spring and Autumn Period. In addition, a few pieces that were carved by grind carv- 


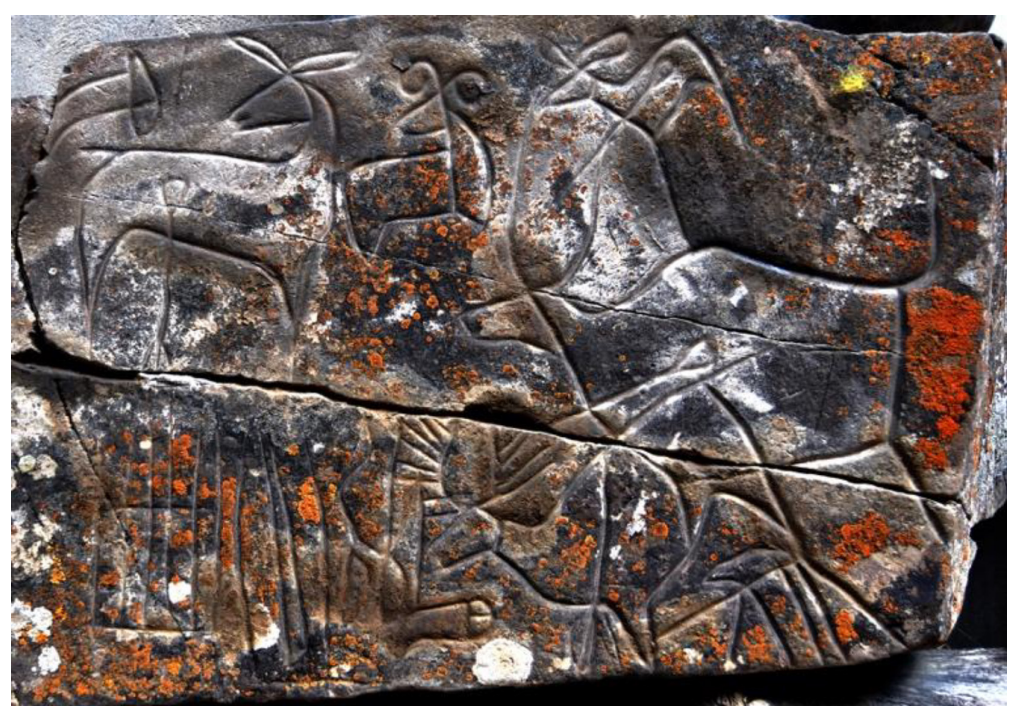

Fig. 19. Dongguo rock art (provided by Yushu Museum). The rock-face is $49 \mathrm{~cm}$ high, $93 \mathrm{~cm}$ wide. The production techniques are grind carving. There are 3 deer rock art, 1 sheep rock art, 1 cattle rock art, and other images like genital organ, arrow, and vertical line on the rock-face (Nimaliangcai, 2016)

ing technique had obviously different model. Especially in one work in Dongguo, the deer was "turning round" (Fig. 19). This kind of model also embodied in the Scythian artistic style. Referring to one grind carving deer rock art of the Lushan Rock Art in Qinghai (Tang, Zhang, 2001), the age of the Dongguo rock art was roughly in Qin and Han dynasties.

To explore the age of the rock art in the Tongtian River Basin, we should analyze them in comparison to the whole range of Qinghai rock art. From 1985 to 1988, the Qinghai Provincial Institute of Archaeology and Capital Normal University jointly carried out an investigation on rock art, discovering 13 rock art sites, which were mainly distributed in the Hehuang Valley in the east and southeast part of Qinghai and the Haixi, Haibei, Hainan Autonomous Prefectures of Qaidam Basin. Professor Tanghuisheng, using the comprehensive comparative analysis and verified by the micro corrosion-cohort analysis, divided the rock art in this area into four stages: the first stage was in $1000 \mathrm{BC}-500 \mathrm{BC}$; the second stage in 500 $\mathrm{BC}-300 \mathrm{BC}$; the third stage was around the Christian era; while the fourth period was in the 7th-9th century AD. This age division is quite credible (Tang, Zhang, 2001). Combined with this staging, we analyzed the production techniques of each stage's rock art. In the first stage, the whole-image chiseling was the main technique, while the linearly chiseling technique was secondary; The second stage was dominated by the line carving technique; in the third stage, the grind carving technique, using metal tools, was mainly used; while the fourth stage was dominated by the scratching technique.

According to the combination of the regional distribution characteristics of the Tongtian River Basin's rock art, the comparative analysis on the production techniques, especially carriage and deer rock art and the production techniques in eastern Qinghai, we believed that the relative ages of the Tongtian River Basin's rock art were as follows (Table 2).

The dating has always been one of the biggest problems in the research of rock art, the international rock art circle has used technologies such as carbon-14, cationic ratio, AMS and micro-corrosion to directly date rock art, but the direct dating methods has serious limitations and high costs. China has a unique traditional culture and rich historical materials, which provide a favorable condition for the comparative study on rock art. Currently, 
Table 2

\begin{tabular}{|c|c|}
\hline Production techniques & Age dating \\
\hline Whole-image chiseling & $\begin{array}{c}\text { Shang Dynasty } \\
(1600 \text { BC-1100 BC })\end{array}$ \\
\hline Linearly chiseling & From the early Zhou Dynasty to the Warring States Period \\
& (1100 BC-221 BC) \\
\hline Line carving & From the Warring States Period to the Western Han Dynasty \\
& (476 BC-25AD) \\
\hline Grind carving & $\begin{array}{c}\text { Qin and Han Dynasty } \\
\text { (221 BC-25AD) }\end{array}$ \\
\hline scratching & the Ancient Tibetan Empire Period \\
& $(618-842$ AD)
\end{tabular}

Chinese scholars analyze the dating of rock art through the comparative study on materials of historical documents, archaeology, anthropology, ethnology and so on, which is at present quite advisable (For example, Qinghai Rock Art: A Study of Binary Oppositional Thoughts and Concepts in Prehistoric Art (Tang, Zhang, 2001) and Research on the Yinshan Rock Art (Wang, Zhang, 2012)). Of course, the direct dating of rock art is still in the exploratory stage and the final solution of dating problem needs new breakthroughs in technology and further multidisciplinary cooperation.

Excursus: In September 2016, we were invited to participate in the "Tongtian River Ba- sin's rock art" seminar and to investigate the rock art in this area, which gave us the opportunity to observe the characteristics of rock art on the spot. In the end of this paper, we must thank Curator Nimajiangcai and his academic team for their hard work in the past few years. It was their efforts that provided rich, detailed first-hand research materials for rock art circle, and laid a solid foundation for the in-depth research of Yushu rock art. Besides, we'd like to thank Nimajiangcai, Xiaoxia, Aiping for providing clear picture materials for this paper and thank Wangqianqian and Liguohua of the Institute of Archaeology of Qinghai Province for sending us archaeological materials.

\section{References}

Liu Changming (2014). The hydro-geography of China. In Science Press. Beijing, 637-638.

NimaJiangcai (2016). Yushu Rock Art: Tongtian River. In Qinghai People’s Publishing House. Xining, 409 p.

Sun Ji (2008). Material and Cultural Information of the Han Dynasty. In Shanghai Ancient Books Press, Shanghai, 111-133.

Sun Ji (2016). Chinese Ancient Carriage Culture. In Shanghai Ancient Books Press, Shanghai, 37-82.

Tang Huisheng, Zhang Wenhua (2001). Qinghai Rock Art: A Study of Binary Oppositional Thoughts and Concepts in Prehistoric Art. In Science Press, Beijing, 167 p.

The Annals of Yushu (2005). Sanqin Publishing House. Xi`an. P3.

Wang Xiaokun, Zhang Wenjing (2012). Research on the Yinshan Rock Art. In China social sciences press. Beijing, 113-116.

Zhang Wenjing (2013). The Carriage Rock Art of Yinshan Area. In Northern Cultural Relics (1). 


\title{
Наскальные рисунки в бассейне реки Тунтянь (Тибетское плато, Китай)
}

\author{
Чжан Вэньцзина, Ван Сяокунь \\ ацентральный университет национальностей \\ Китай, Пекин, Хайдянь \\ ${ }^{\sigma}$ Китайский народньй университет \\ Китай, Пекин, Хайдянь
}

\begin{abstract}
Аннотация. В последние годы музей Юйшу проводил систематические исследования наскальных рисунков в бассейне реки Тунтянь в своей префектуре. Были обнаружены 1230 плит (более 1700 изображений). Данная статья представляет статистический и сравнительный анализ найденных образцов. По содержанию и технологиям нанесения наскальное искусство этого района можно разделить на две большие группы: западную - верхняя часть бассейна реки, расположенная до слияния рек Тунтянь и Чумар (река Кумалай), и восточную - нижняя часть бассейна от слияния до реки Батанг в Юйшу. Вторую область можно подразделить еще на три части.

Большая часть изображений представляет собой фигурки животных. Як и олень главные темы обеих групп. Кроме того, встречаются символы, персонажи, пагоды, повозки и проч. Обе группы, помимо общих черт, имеют и свои особенности. Типологический анализ технологий нанесения позволяет предположить, что для создания рисунков повозок и оленей в основном использовался способ долбления всего изображения (техника периода династии Шан). Наскальные рисунки, высеченные линейно, относятся ко времени от ранней династии Чжоу до периода Сражающихся царств. Техника резьбы по линиям датируется периодом Сражающихся царств времен Западной династии Хань, а техника шлифования, вероятно, временем династий Цинь и Хань. Изображения, где в основном использовалась техника царапания, восходит к периоду Древней Тибетской Империи (618-842 гг.н.э.).
\end{abstract}

Ключевые слова: наскальное искусство, долина реки Тунтянь, Тибетское плато.

Статья подготовлена по программе «Изучение наскального искусства в евразийской степи» (18YYА02), которую поддерживает научный исследовательский фонд Университета Жэньминь, Китай.

Научная специальность: 07.00.00 — исторические науки и археология. 